\title{
Refugee Integration in Canada: A Survey of Empirical Evidence and Existing Services
}

\author{
Soojin Yu, Estelle Ouellet, and Angelyn Warmington
}

\section{Abstract}

While a fairly large body of empirical research and policy documents exists on immigrant integration in Canada, studies on refugee integration are scarce. This paper attempts to fill this gap. It summarizes what is known about refugees' economic and socio-cultural integration patterns in Canada and what integration services are available to them in order to identify empirical knowledge gaps and service gaps. Whenever salient and possible, the distinction among the Government-Assisted Refugees, Privately Sponsored Refugees, Landed-in-Canada Refugees and refugee claimants is made.

\section{Resume}

Alors qu'il existe une masse assez considérable de documents de recherches empiriques et de politiques officielles ayant trait à l'intégration des immigrants au Canada, les études sur l'intégration des réfugiés sont rares. Cet article essaye de combler cette lacune. Il résume ce qui est connu sur les tendances d'intégration économique et socioculturel des réfugiés au Canada ainsi que sur les services d'intégration qui leurs sont disponibles; cela dans le but d'identifier les lacunes en matière de connaissance empirique et dans les services. Là où c'est notable et possible, la distinction est faite entre les réfugiés pris en charge par le gouvernement, les réfugiés bénéficiant du parrainage privé, les réfugiés reconnus comme tels au Canada et les demandeurs du statut de réfugié.

\section{Introduction}

Refugees have consistently made up over 10 per cent of the annual inflow of newcomers to Canada in the last decade. ${ }^{1}$ However, while a fairly large body of empirical research and policy documents exists on immigrant integration in Canada, studies on refugee integration are scarce. Very few Canadian studies on refugees have a truly national scope or contain systematic empirical analyses, and many are limited to reporting on one specific refugee community. ${ }^{2}$

Despite the lack of a shared definition for "successful integration" in academic or policy discourse, ${ }^{3}$ most scholars and policy makers in Canada and elsewhere agree with a description of "integration" as a "dynamic, multi-faceted two-way process which requires adaptation on the part of the newcomers, but also the society of destination." ${ }^{4}$ Hence, most generally accept that "integration," as opposed to one-way assimilation, outright marginalization, or segregation, is desirable. ${ }^{5}$ In fact, Canada's domestic policy and international obligation reflect these views. Section 3(e) of the Immigration and Refugee Protection Act (IRPA) states that one of its objectives is "to promote the successful integration of permanent residents [immigrants and refugees] into Canada while recognizing that integration involves mutual obligations for new immigrants and Canadian society." Likewise, Article 34 of the 1951 Convention relating to the Status of Refugees, to which Canada is a signatory, states that " $[t]$ he Contracting States shall as far as possible facilitate the assimilation [integration] and naturalization of [domestic asylum] refugees." This paper considers both directions of integration by examining the patterns of refugee integration into the Canadian society on the one hand and the services that are offered to refugees on the other. 
A vast array of indicators is used in the literature to quantify the many facets of integration. Examples include labour force participation, income, house ownership, wealth, residential segregation, language skills and use, educational attainment, social networks, cultural consumption patterns, physical and mental health, fertility, marital status, and various attitudes. However measured, refugees and immigrants are likely to face common barriers towards achieving integration in Canada: lack of official language skills, difficulty finding an adequate job, and having foreign credentials recognized, among others.

Nonetheless, there are at least two reasons why refugee integration issues may be distinct from those concerning other immigrants, warranting more studies focusing on refugees. First, refugees are admitted to Canada primarily on humanitarian rather than economic grounds. The key selection criterion for immigrants is their ability to establish: economic potential for the principal skilled worker and business applicants, and the presence of economic and social supports in Canada for family class. In contrast, the primary consideration for refugees is their need for Canada's protection. Given this difference at the selection stage, it is not unrealistic to expect different patterns of integration between refugees and immigrants. Second, the circumstances surrounding refugees' migration are likely to be much more traumatic than voluntary immigrants,' which may impact their integration patterns and call for specialized integration services, such as counselling and mental health care, in addition to generic integration services.

This article seeks to summarize what is known about refugee integration patterns and needs in Canada in order to identify knowledge gaps. The second section provides a brief introduction to Canada's refugee protection system and its refugee population characteristics. The third section describes the patterns of refugees' economic and socio-cultural integration as portrayed in nationally representative databases and empirical literature, and identifies the empirical knowledge gaps on refugee integration in Canada. The fourth section describes the existing services addressing refugees' various integration needs, and identifies the service gaps for refugee integration in Canada. This paper concludes by summarizing the gaps identified and suggesting future research directions regarding refugee integration in Canada.

\section{Refugee Population Characteristics in Canada}

Canada's refugee protection system consists of two main components: the in-Canada refugee protection system, and the refugee and humanitarian resettlement program. Persons making claims through the in-Canada refugee protection system are referred to as "refugee claimants" or "claimants" in this paper. Claimants who are determined to be in need of Canada's protection at the Immigration and Refugee Board (IRB) are granted the "protected person" status; rejected claimants become subject to removal. Protected persons who subsequently become permanent residents are referred to as "Landed-in-Canada Refugees" (LCRs). The resettlement program involves the selection of refugees overseas either as Government-Assisted Refugees (GARs), who are referred by UNHCR and supported through federally funded Resettlement Assistance Program (RAP), or as Privately Sponsored Refugees (PSRs), who are sponsored and supported by voluntary groups. Whenever salient and possible, the distinction among these different groups of refugees is made throughout this paper. In addition, refugees are situated in the larger context by being compared to other categories of immigrants as well as to Canadian averages.

Figure 1: Refugees Granted Permanent Residence in 2005 by Category

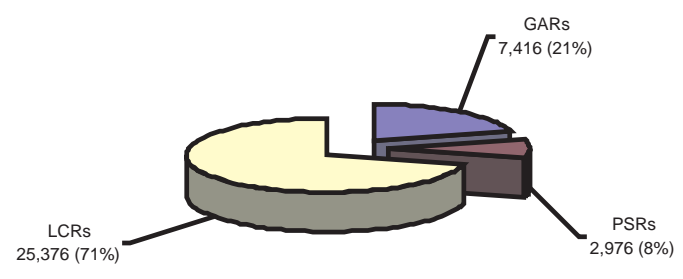

Source: Facts and Figures 2005, Citizenship and Immigration Canada

In 2005, Canada granted permanent residence to 35,768 refugees. ${ }^{6}$ Figure 1 shows that more than two thirds of refugee inflow is composed of LCRs and their dependents from overseas (71 per cent), followed by GARs ( 21 per cent) and PSRs (8 per cent).

The main characteristics of refugees and immigrants who were granted permanent residence to Canada in 2005 may be presented in terms of raw figures ${ }^{7}$ or historical figures. ${ }^{8}$ Gender is evenly distributed across the three categories of refugees and the other immigrant categories (family and skilled workers). ${ }^{9}$ In terms of age, the vast majority (more than 80 per cent) is under 45 in all immigrant and refugee categories. The family class has a similar age distribution to PSRs and GARs while skilled workers' age distribution is more similar to LCRs.'

Among refugee categories, GARs are the youngest with 37 per cent under the age of 15 and less than 10 per cent over the age of 44 . PSRs are also fairly young, with 26 per cent under the age of 15 and 10 per cent over the age of 44 . 
LCRs are the oldest, with 15 per cent under 15 and 16 per cent over 44. In terms of areas of birth, the largest source area is Middle East and Africa for refugees while it is Asia and Pacific for other immigrants. For example, roughly 30 per cent of refugees arriving in 2005 come from the Asia/Pacific region, while almost 60 per cent of the family class and skilled workers come from that part of the world. Among refugee categories, areas of birth vary between LCRs on the one hand and GARs and PSRs on the other: while almost two thirds of PSRs and 42 per cent of GARs come from Middle-East/Africa, less than a third of LCRs do; 30 per cent of LCRs come from Latin America compared to 21 per cent of GARs and 5 per cent of PSRs; 13 per cent of LCRs come from Europe and Central Asia versus 3 per cent of PSRs and 9 per cent of GARs.

Table 1 summarizes the educational attainment upon arrival in 2005 of refugees and immigrants. ${ }^{10}$ Only refugees who are 15 years of age or older are examined because the above-mentioned differences in age composition among categories may impact the education level. Among the three refugee categories, LCRs are by far the most educated. About half of the LCRs category has either thirteen or more years of schooling or a trade certificate/diploma or a university degree. In comparison, only one quarter of the GARs and PSRs category have attained this education level. In fact, 48 per cent of GARs and 36 per cent of PSRs have less than nine years of schooling. In terms of other immigrant categories, the family class's educational attainment is simi- lar to LCRs but higher than GARs and PSRs, as slightly more than half of its population has either thirteen or more years of schooling or a trade certificate/diploma or a university degree. Skilled workers are by far the most educated of all immigrant categories with over 80 per cent with thirteen or more years of education. Overall, about 70 per cent of all arrivals in 2005 reported thirteen or more years of education.

\section{Refugee Integration in Canada: Empirical Evidence}

What do the literature and nationally representative databases tell us about the patterns of refugees' economic and socio-cultural integration in Canada? For the purpose of this paper, economic integration is measured by employment rate and employment earnings at one and five years after the receipt of permanent resident status. Socio-cultural integration is measured by available indicators, i.e., Canadian citizenship, general satisfaction level, and familial networks, as no data is available on other indicators, such as social engagement and political participation. Whenever possible, the three categories of refugees are distinguished and compared to other immigrant categories. ${ }^{11}$

\section{Economic Integration of Refugees}

Through the Longitudinal Survey of Immigrants to Canada (LSIC), immigrants who arrived in Canada between October 1, 2000, and September 30, 2001, were interviewed at six months, two years, and four years after arrival in Canada as

Table 1:

Level of Education at Arrival by Category, Refugees and Immigrants Aged 15 Years and Older Who Were Granted Permanent Residence in 2005

\begin{tabular}{|c|c|c|c|c|c|c|}
\hline & LCRs & GARs & PSRs & $\begin{array}{l}\text { Family } \\
\text { Class }\end{array}$ & $\begin{array}{c}\text { Skilled } \\
\text { Workers } \\
\text { Principal } \\
\text { Applicants }\end{array}$ & $\begin{array}{c}\text { All } \\
\text { Refugees } \\
\text { and } \\
\text { Immigrants }\end{array}$ \\
\hline 0 to $9 \mathrm{yrs}$ & $19 \%$ & $48 \%$ & $36 \%$ & $20 \%$ & $8 \%$ & $14 \%$ \\
\hline 10 to $12 \mathrm{yrs}$ & $30 \%$ & $26 \%$ & $37 \%$ & $23 \%$ & $9 \%$ & $16 \%$ \\
\hline 13 or more & $13 \%$ & $7 \%$ & $7 \%$ & $10 \%$ & $6 \%$ & $8 \%$ \\
\hline $\begin{array}{l}\text { Trade } \\
\text { Certificate/Diploma }\end{array}$ & $19 \%$ & $7 \%$ & $12 \%$ & $17 \%$ & $14 \%$ & $16 \%$ \\
\hline University Degree & $19 \%$ & $12 \%$ & $7 \%$ & $29 \%$ & $63 \%$ & $46 \%$ \\
\hline TOTAL & 16,950 & 4,642 & 2,217 & 63,352 & 52,266 & 204,633 \\
\hline
\end{tabular}

Source: Facts and Figures 2005, Citizenship and Immigration Canada 
permanent residents. Since tracking down the date of arrival of LCRs is complex and since LCRs may have already been in Canada for a certain period of time when obtaining their permanent residence (or "landed"), LSIC's "refugees" category mainly includes GARs and PSRs. ${ }^{12}$ Figure 2 compares employment rates by immigrant category for principal applicants from the two first interviews. (In this section, the economic outcomes of solely principal applicants (PAs) of each immigration category are examined. The rationale for this is the practice of linking economic performance to the definition of each category, i.e. PAs rather than spouse, partners, and dependents.) Skilled workers have the highest employment rates both at six months (60 per cent) and at two years since arrival (over 70 per cent) whereas refugees have the lowest employment rates (20 per cent and over 40 per cent respectively). Interestingly, refugees also show the greatest improvement between the two interviews with an increase of over 20 percentage points. In comparison, family class shows the weakest progression, from almost 40 per cent at six months after arrival to less than 50 per cent at two years since arrival.

Figure 2: Employment Rate at 6 Months and 2 Years after Arrival by Immigrant Category (Principal Applicants)

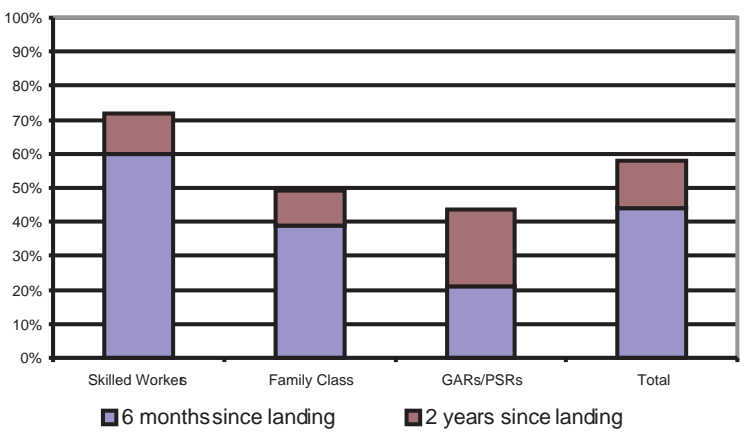

Source: Longitudinal Survey of Immigrants to Canada, Statistics Canada (weighted sample size)

Another national scale database on immigrants and refugees is Immigration Database (IMDB). Despite being limited to the tax-filing population, IMDB remains an important source of information on the economic outcomes of refugees since this large database provides the opportunity to disaggregate immigrants and refugees by category. ${ }^{13}$ Figures 3 and 4 compare the employment earnings of refugee and immigrant categories (principal applicants) at one and five years since "admission to permanent residence" (landing) for tax years 1995 through 2003. This means that immigrants and refugees in Figure 3 are not identical to those in Figure 4, as Figure 3's population landed from 1994 through 2002 while
Figure 4's arrived from 1990 through 1998. However, both the earnings and the relative positions among immigrant and refugee categories mostly remain stable among the various landing cohorts, making intercategory comparison across time meaningful.

At one year since landing (Figure 3), refugees and family class show the lowest average annual employment earnings (under \$20,000) while, as expected, the skilled workers category and the Canadian average show the highest average annual employment earnings, at around \$30,000 (except for skilled workers who landed in 2001-2002, who report average employment earnings of around $\$ 25,000$ in 2002-2003). Among refugees, the earnings of PSRs and LCRs are similar at just below $\$ 20,000$ whereas GARs report the lowest earnings at around $\$ 10,000$. The difference between GARs on the one hand and PSRs and LCRs on the other may be explained by the fact that (1) most LCRs have been in the country for a certain period by the time they land, thus have an advantage over newly arrived GARs and PSRs, and (2) sponsors often arrange PSRs' employment prior to their arrival unlike GARs, who are financially supported by the RAP. Therefore, even though LCRs and PSRs have higher average earnings than GARs one year after arrival, drawing conclusions on GARs' lower ability to integrate economically should be made cautiously.

Figure 4 shows how employment earnings compare at five years since landing. All categories report higher earnings than at first year since landing. Nevertheless, refugees and family class still show the lowest average annual employment earnings, within the $\$ 20,000$ to $\$ 25,000$ range, while skilled workers continue to show the highest employment earnings, reporting between $\$ 40,000$ and $\$ 50,000$ depending on the year of landing. The Canadian average is in between, at roughly $\$ 30,000$. Although still very similar within the $\$ 20,000$ to $\$ 25,000$ range, interesting patterns emerge among the three refugee categories. At five years after arrival, PSRs have overtaken LCRs, albeit slightly. GARs, interestingly, show marked differences between landing cohorts. GARs who landed in 1994 and 1995 (tax years 1999 and 2000) show higher employment earnings than their peers who arrived before or after this period at five years since landing. In fact, these two cohorts show higher earnings than their LCR and PSR peers. A closer examination of the database showed that these two cohorts were composed mainly of highly educated refugees from Bosnia-Herzegovina. ${ }^{14}$

In short, the employment earnings of refugees at first and fifth year since landing are comparable to family class immigrants' earnings, and, as expected, much lower than skilled worker immigrants and Canadian average's figures. This finding is consistent with the pattern of divergent earnings 
between refugee and family class entrants on the one hand and the economic class on the other as noted in a study by DeVoretz, Pivnenko, and Beiser..$^{15}$ Among the refugee categories, although GARs show lower employment earnings than PSRs and LCRs at one year since landing, at five years since landing there is very little difference among the three categories for those arriving in Canada in 1994 and later.

Figure 3: Employment Earnings at One Year after Arrival of Immigrants and Refugees Granted Permanent Residence in 1994-2002 by Category (Principal Applicants) and Canadian Average

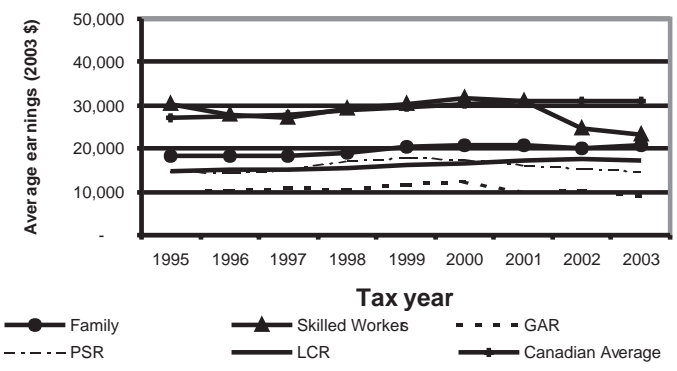

Source: Immigrants: Longitudinal Immigration Database (IMDB), Compendium Tables 2003, Statistics Canada, online: IMDB-BDIM Homepage, http://www24.statcan.ca (accessed 11 May 2007);

Canadian average: Cansim, tables 202-0402 and 326-0002, Statistics Canada, online: Cansim http://cansim2.statcan.ca (accessed 11 May 2007).

Figure 4: Employment Earnings at Five Years after Arrival of Immigrants and Refugees Granted Permanent Residence in 1990-1998 by Category (Principal Applicants) and Canadian Average

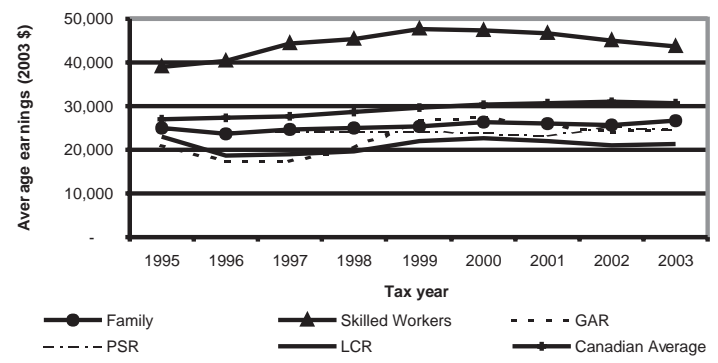

Source: Immigrants: Longitudinal Immigration Database (IMDB), Compendium Tables 2003, Statistics Canada, online: IMDB-BDIM Homepage http://www24.statcan.ca (accessed: 11 May 2007);

Canadian average: Cansim, tables 202-0402 and 326-0002, Statistics Canada, online: Cansim http://cansim2.statcan.ca (accessed 11 May 2007).

\section{Socio-cultural Integration of Refugees}

Socio-cultural integration is a much more elusive concept to define and to quantify than economic integration. Consistent with this difficulty, empirical evidence on refugees' socio-cultural integration patterns, or all integration patterns outside of the economic sphere for that matter, is extremely scarce. This section summarizes the very few studies that either remotely or more directly examine the socio-cultural integration patterns of refugees in Canada.

LSIC provides some assistance in this regard. ${ }^{16}$ If taking the extra steps to acquire the Canadian citizenship is any indication of successful socio-cultural integration, Table 2 shows that refugees (GARs and PSRs) are doing extremely well: they show the highest percentage (97 to 99 per cent) of having obtained, applied for, or intending to apply for naturalization among all categories ( 87 to 95 per cent) by the fourth year of arrival. ${ }^{17}$ However, given that refugees, by definition, do not benefit from the protection of another state, their high citizenship acquisition rate does not come as a surprise.

In terms of various attitudes towards Canada, a similar proportion of refugees to other immigrant categories cited "Canada's better quality of life" as one of the reasons why they would like to remain in Canada permanently: 55 per cent of refugees (GARs and PSRs) compared to 58 per cent of economic and 49 per cent of family class immigrants. However, they show a greater appreciation of certain aspects of Canada's life, namely "peace/absence of war" and "political or religious freedom," than other immigrant categories (Table 2 ). This reflects the particular circumstances surrounding refugees' migration (e.g. political unrest, persecution, etc.) that are distinct from motivations that encourage economic or family immigrants to come to Canada. However, the results may not be as high as one might expect for persons who have come to Canada specifically to escape persecution or war and thus warrant further analysis.

Another study on socio-cultural integration comes from a smaller study based on 525 interviews; conducted with adult GARs and PSRs destined to Alberta, it examines the daily interactions of refugees with their surroundings in greater depth. ${ }^{18}$ As shown in Table 3, the study found that refugees spend more time with co-ethnic friends ( 47 per cent) and extended family living outside of household (26 per cent) than with "Canadian" friends ( 21 per cent), neighbours (21 per cent), or even families who sponsored them (7 per cent). Unfortunately, comparable studies on other immigrant categories in Canada are unavailable.

The impact of such co-ethnic contacts on socio-cultural and economic integration outcomes is unclear. A subsequent study based on the same sample found that living in close proximity to a family member (i.e., child, parent, or sibling) 
Table 2: Citizenship Status and Intentions/Reasons for Staying in Canada Permanently by Category

\begin{tabular}{||l|c|c|c|c||}
\hline \hline & $\begin{array}{c}\text { Per cent who } \\
\text { obtained, applied } \\
\text { or intend to } \\
\text { apply for } \\
\text { citizenship }\end{array}$ & $\begin{array}{c}\text { Per cent who } \\
\text { cited “better } \\
\text { quality of life" as } \\
\text { a reason for } \\
\text { wanting to stay } \\
\text { in Canada } \\
\text { permanently }\end{array}$ & $\begin{array}{c}\text { Per cent who } \\
\text { cited “peace/ } \\
\text { absence of war" } \\
\text { as a reason for } \\
\text { wanting to stay } \\
\text { in Canada } \\
\text { permanently }\end{array}$ & $\begin{array}{c}\text { Per cent who cited } \\
\text { "political or } \\
\text { religious freedom" } \\
\text { as a reason for } \\
\text { wanting to stay in } \\
\text { Canada permanently }\end{array}$ \\
\hline Economic & $91.3 \%-94.6 \%$ & $58.4 \%$ & $31.1 \%$ & $11.1 \%$ \\
\hline Family Class & $87.3 \%-90.4 \%$ & $48.6 \%$ & $20.8 \%$ & $28.5 \%$ \\
\hline GARs/PSRs & $97.2 \%-98.8 \%$ & $54.7 \%$ & $53.5 \%$ & $15.8 \%$ \\
\hline TOTAL & $90.7 \%-93.8 \%$ & $55.4 \%$ & $29.6 \%$ & $16.7 \%$ \\
\hline \hline
\end{tabular}

Source: Grant Schellenberg and Hélène Maheux (April 2007), Tables 4:17 (LSIC).

Table 3: Refugees who Reported Spending Time "Daily or Often" with...

\begin{tabular}{|l|r|r|r|r|r|r|c||}
\hline \hline & $\begin{array}{c}\text { Co-ethnic } \\
\text { friends }\end{array}$ & $\begin{array}{c}\text { Family } \\
\text { outside } \\
\text { household }\end{array}$ & $\begin{array}{c}\text { Other } \\
\text { Canadian } \\
\text { friends }\end{array}$ & Neighbours & $\begin{array}{c}\text { Other } \\
\text { immigrants }\end{array}$ & $\begin{array}{c}\text { People } \\
\text { from } \\
\text { work }\end{array}$ & $\begin{array}{c}\text { Sponsor f } \\
\text { amily }\end{array}$ \\
\hline$\%$ & $47 \%$ & $26 \%$ & $21 \%$ & $21 \%$ & $14 \%$ & $12 \%$ & $7 \%$ \\
\hline $\mathrm{N}$ & 224 & 136 & 106 & 112 & 72 & 64 & 39 \\
\hline
\end{tabular}

Source: Navjot K. Lamba (2003), 343.

had a negative impact on the quality of employment. According to the author, this is presumably due to the need for care. However, the same study found that refugees who sought familial and extra-familial aid in finding a job found better quality employment than their peers who did not have such networks. ${ }^{19}$ The impact of co-ethnic networks on refugee integration outcomes needs to be clarified.

\section{Summary}

Overall, in terms of economic integration, refugees have lower economic outcomes than other categories of immigrants. Compared to skilled workers, refugees show a markedly lower employment rate and lower employment earnings. The difference between refugees and family class immigrants is smaller. Although refugees' economic performance improves as their time in Canada increases, they continue to under-perform compared to other immigrant categories. Among the different categories of refugees, in the first year since landing, LCRs and PSRs outperform GARs in terms of employment earnings. However, for more recent years, by the fifth year after landing, these differences in economic outcomes disappear and all three refugee groups show similar economic outcomes. In terms of socio-cultural integration of refugees, there is a dearth of evidence about this 10 per cent of Canada's annual intake.

In short, more research is needed on the causes of economic performance differential, and on the meaning, patterns, and causes of socio-cultural integration of refugees. In addition, the analysis of the statistics presented in this section elicits many further questions. For example, what is the impact of family size on average earnings for refugees and other immigrant categories? Do remittances affect average earnings of the immigrant and refugee categories differently? How does the trauma suffered by refugees and immigrants affect their social-cultural integration? Is there a gender difference in economic and socio-cultural integration patterns? These questions as well as many other caveats remain to be investigated.

\section{Survey of Existing Integration Services}

The previous section sought to identify the empirical knowledge gaps for refugee integration in Canada. This section 
aims at identifying service gaps, if any, by examining currently available integration services for refugees in Canada. It does so by first reviewing the relevant literature and then examining the federal and provincial funding sources and programs as well as an array of service-providing organizations across the country.

For the purpose of this paper, an "integration service" is defined as a direct or indirect service whose goal is to facilitate any aspect of social, emotional, physical, or economic adjustment or settlement of newcomers in Canada. In other words, integration services are designed to assist newcomers who intend to settle in Canada permanently. This focus on permanent settlement is reflected in the various Terms and Conditions of integration services funded by the federal government, whose main clients are clearly defined as: (1) permanent residents of Canada, (2) protected persons as defined in Section 95 of IRPA, and (3) persons who have received the initial approval of the permanent residence. The focus on newcomers means that Canadian citizens are not eligible to access these services. ${ }^{20}$

Given this focus on permanent residents, a reminder note on the difference in status among the resettled refugees (GARs and PSRs), LCRs, protected persons, and refugee claimants is warranted. Most of the resettled refugees physically arrive in Canada as permanent residents. It is therefore no surprise that they are eligible to access most integration services upon arrival. In fact, as will be shown below, some resettled refugees even start accessing integration services overseas, before setting foot on the Canadian soil.

The story is very different for the would-be refugee claimants who arrive on Canadian soil without a permanent resident status. Many even arrive without a valid temporary resident status. Once these individuals submit their refugee protection claims, they are granted temporary resident status. As temporary residents, claimants are not eligible for settlement services, which are intended to facilitate permanent settlement and integration into Canadian society. (The debate surrounding whether integration services should be extended to claimants is highly polarized. Since it is beyond the scope of this paper to substantiate this debate, this paper suggests this topic as a subject for future research in the conclusion.) If claimants are determined to be persons in need of Canada's protection at the IRB, they are given the protected person status, which can be considered a permanent status as it indefinitely guarantees nonrefoulement. Accordingly, protected persons are eligible to access integration services. If determined not to be in need of protection, they are subject to removal. Protected persons are subsequently allowed to apply for, and generally obtain, the permanent resident status. At this point, they (and their overseas dependents) are recorded as LCRs.
LCRs are eligible to access integration services generally offered to other immigrants.

Many integration service providers in Canada target all newcomers, including refugees, while some specialize in certain ethnic groups or only refugees or some categories of refugees. Although funding sources vary, most services are delivered by non-governmental organizations. Integration services to refugees are grouped into three areas: reception, orientation, and housing; employment and language; and counselling and social support. They are discussed in detail below.

\section{Reception, Orientation and Housing}

Resettled refugees are eligible to attend Canadian Orientation Abroad sessions, in which employment, rights and responsibilities, Canadian culture and life, among other things, are discussed before they depart for Canada. Upon arrival, most GARs are received at the airport by staff from agencies funded by the federally funded RAP and/or provincial funding sources. PSRs, on the other hand, are met at the airport by their sponsors. The service provider or sponsor will have arranged temporary or permanent accommodation for the refugee. Resettled refugees are eligible to receive orientation and housing support services immediately after arrival and may be directed to these and other services by their sponsor.

Refugee claimants, on the other hand, are not received by anyone when they arrive at a port of entry unless they have friends or family already residing in Canada. Instead, they rely on word-of-mouth for information as to where to go. According to one study in Toronto that looked at the initial housing situation of sponsored refugees and claimants $(n=44), 37.5$ per cent of refugee claimants spent their first night with friends or family. One third of respondents spent their first night in a hostel or shelter, and another third wherever they could find a place, such as "a motel, a church, a stranger's house or even outside in a park" and later moved into a shelter. ${ }^{21}$ In larger metropolitan areas, where most refugee claimants reside, they may access refugee-specific shelters, such as Romero House in Toronto, which provide counselling, orientation, and support services to claimants. In fact, of families using emergency shelters in Toronto in 1999, 24 per cent were found to be refugee claimants. ${ }^{22}$

Although mostly excluded from the federally funded integration services, refugee claimants are eligible for some integration services in certain provinces. For example, Ontario's Newcomer Settlement Program assists refugee claimants as well as other newcomers. In Quebec, refugee claimants are eligible to receive support services in finding permanent accommodation, but are not eligible for other 
orientation and referral programs. ${ }^{23}$ However, a study in Toronto found that while only a minority of service providers receive funding to serve refugee claimants, 81 per cent said they provide direct services to claimants. ${ }^{24}$ Refugee claimants are generally eligible to receive services after a positive refugee determination at the IRB (when they become protected persons), by which time they will have resided in Canada for some time. By the time they are granted the permanent resident status as LCRs, they often no longer need to access initial orientation and referral services.

Regardless of categories, studies indicate that low income and high rents constitute a major obstacle for all types of refugees in finding permanent housing. This barrier is exacerbated by the fact that many refugees, like immigrants, tend to settle in large metropolitan areas where housing is most expensive. According to the PSR Evaluation, "focus group participants [sic] cited the high cost of housing as being a challenge to resettlement and it seemed common for the participants to have lived with their sponsors for a certain period of time upon arriving in Canada." 25 For GARs, low RAP rates are problematic. According to the RAP Evaluation, " $[\mathrm{t}]$ he majority of RAP focus group respondents stated that they had a gap of approximately 25 per cent between the support provided for rent and the actual amount they pay. Many respondents stated that they were using funds that were originally allocated for food and basic needs to meet rent and utility payments." 26 One study of newcomers in Vancouver found that, when asked about the main difficulties experienced in finding housing, 91 per cent of refugee respondents $(n=75)$ cited lack of affordability (or high rent) as the main obstacle. ${ }^{27}$ Two small surveys indicate that refugees often spend more than 50 per cent of their income on rent. ${ }^{28}$ For example, of 146 newcomer GAR respondents in British Columbia, 54 per cent spent more than 50 per cent of their income on rent. ${ }^{29}$ Large household size often exacerbates this problem. ${ }^{30}$ While housing support services have a role to play, increasing refugees' income and employment earnings may also be important.

\section{Employment and Language}

GARs, PSRs, LCRs, and protected persons have access to federally and provincially funded employment and language services that cater to all permanent resident newcomers. Refugee claimants who are waiting for their status determination may not have access to employment services, depending on the province in which they reside, but they may apply for temporary work permits.

Employment services often involve workshops on resume writing and interview skills, and job search tools. A number of programs funded by federal and provincial governments assist all immigrant and refugee newcomers with their job search. For example, the federal government funds settlement services, including employment-related services, through the Immigrant Settlement and Adaptation Program. These services are open to permanent residents and refugees who have received a positive refugee status determination by the IRB. At the provincial level, the Newcomer Settlement Program in Ontario and the Immigration Settlement Program in Nova Scotia fund the same type of programming. In Ontario, services may be offered to claimants, while in Nova Scotia, claimants are eligible for services after receiving a positive refugee determination only. ${ }^{31}$ Other employment services target those with already high language and professional skills. For example, the Enhanced Language Training program provides advanced work-related language training with a bridge-to-work component for newcomers; the Ontario Internship Program for Internationally Trained Professionals creates job placement opportunities for professional immigrants.

Refugees share barriers to employment similar to those faced by other immigrants, such as lack of official language skills, lack of Canadian work experience, difficulty in foreign credential recognition, and discrimination. However, as presented below, some barriers may be specific to refugees, or at least more common and intense for refugees than for the overall immigrant population.

First, refugees, particularly GARs and PSRs, show a poor self-assessment of official language skills upon landing: 69 per cent of GARs and PSRs are unable to speak French or English upon landing compared to 6 per cent of LCRs and 36 per cent of other immigrant categories. ${ }^{32}$ (LCRs show better language skills, partly because they have been residing in Canada for some time by the time they are granted permanent residence.) Very little is known about refugee claimants' language skills upon arrival. Perhaps due to their relatively poor language skills upon arrival, resettled refugees are much more likely than other immigrants to receive language training: 57 per cent of GARs and PSRs had received language training within six months of arrival compared to 24 per cent of family class, 25 per cent of skilled workers and 30 per cent of all immigrants and refugees. ${ }^{33}$

Official language skills are essential not only for obtaining employment, but for social integration as well. Language training is accordingly one of the largest program areas in newcomer settlement services. Most English or French language courses across Canada (except in British Columbia, Manitoba, and Quebec) are funded by the federal government's Language Instruction for Newcomers to Canada (LINC) and are not open to refugee claimants. 
Likewise, provincially funded language programs in Quebec are not open to claimants. In Manitoba and in some areas in British Columbia provincially funded English language classes are open to claimants.

Second, as shown in Table 1, refugees, in particular GARs and PSRs, arrive with a low level of formal education. LCRs, the largest group of the three, show marginally higher educational attainment than GARs and PSRs, but it is lower than the educational attainment of other immigrant categories. Low educational attainment is often directly linked to low economic outcomes. A low level of formal education can affect economic outcome indirectly too, as it negatively affects one's ability to acquire an official language, which is a prerequisite for successful employment in Canada. ${ }^{34}$

Third, it has been argued that refugee claimants in particular may find it more difficult to find employment due to the fact that they can only acquire temporary work permits while the IRB decision is pending. Between 2003 and 2005, 76 per cent of refugee claimants 18 years of age and older had a temporary work permit (75 per cent of women and 78 per cent of men). ${ }^{35}$ A study suggested that this temporary status may limit refugee claimants to secondary job markets. ${ }^{36}$ Finally, those who experience pre-migration trauma and settlement stresses may be at risk of developing depression and post-traumatic stress disorder overtime, and, as a result, are more likely to be laid off. ${ }^{37}$

For the refugees who arrive with lower levels of formal education and social capital, fewer official language skills, and greater mental health needs than other immigrants, there may be a need to develop specific employment services that assist these multi-barriered refugees. In addition to the generic language and employment services, employment-related training targeted at newcomers with little formal education may need to be explored.

\section{Counselling and Social Support}

Refugees may have suffered torture, trauma, and difficult migration experiences. Combined with the stresses of resettlement, they may need particular support services. ${ }^{38}$

All refugees, including refugee claimants, have access to the Interim Federal Health program (IFH), which addresses basic and emergency health needs. However, the program does not address mental health needs and high dental needs. Specialized counselling and mental health programs are sometimes provided at the local level by organizations such as the Vancouver Association for the Survivors of Torture and the Canadian Centre for Victims of Torture in Toronto.

Another area of need concerns various types of family counselling. For example, as refugees move from their source to their resettlement country, women may become the primary source of income for the family, leading to changes in gender roles. ${ }^{39}$ This change affects spousal and parental relationships, and may lead to domestic violence. ${ }^{40}$ Some valuable programming exists in these areas, but is limited in scope. For example, specific support for women and parents is sometimes available, such as at the Arab Community Centre of Toronto, the Toronto Chinese Community Services Association, S.U.C.C.E.S.S. in Vancouver, and the Centre for Diverse Visible Cultures in Halifax.

In addition, GARs, PSRs, and LCRs have access to the Settlement Workers in Schools program in seven different communities in Ontario, which helps parents and children adjust to their new roles in the school system. This program involves partnerships with settlement organizations, school boards, and Citizenship and Immigration Canada. It is funded through the Immigrant Settlement and Adaptation Program (ISAP) and is available to all permanent resident newcomers, including protected persons. ${ }^{41}$ In limited cases, similar programs exist throughout the country; for example, school liaising activities are provided by CASA C.A.F.I. in Montreal. It is unclear whether these programs assist refugee claimants.

Likewise, the HOST program and other twinning programs, such as Community Bridging Services in British Columbia and le jumelage interculturel in Quebec, match newcomers with Canadian residents who assist in resettlement and the development of social networks. The HOST program and Community Bridging Services are not open to refugee claimants (except for school-aged children for the Community Bridging Services) until they have received a positive refugee status determination. It is unclear whether other twinning programs across the country are open to refugee claimants. Such programs, albeit limited in quantity, help to build social networks, which facilitate the search for housing and employment and encourage the use of official languages.

\section{Summary}

This section surveyed a wide range of integration services available to GARs, PSRs, LCRs, and refugee claimants at the federal, provincial/territorial, and municipal levels. Integration services were categorized into three groups based on the needs they serve, as summarized in Table 4.

In summary, in terms of access to services, as expected, PSRs and GARs had the widest access. LCRs and protected persons did have similar access to services, but because they have resided in Canada for some time, they were less likely to access the services assisting the earlier settlement stage. Refugee claimants, given their temporary resident status, had the least access to services. They do have access to basic health care under the federally funded IFH, but were ex- 
Table 4: Selected Integration Services Available to Refugees in Canada ${ }^{*}$

\begin{tabular}{|c|c|c|}
\hline $\begin{array}{l}\text { Service } \\
\text { Area }\end{array}$ & Description & $\begin{array}{l}\text { Examples of service- } \\
\text { providing organizations } \\
\text { and programs }\end{array}$ \\
\hline $\begin{array}{l}\text { 1. Orientation, } \\
\text { Reception and } \\
\text { Housing support }\end{array}$ & $\begin{array}{l}\text { - Airport reception for resettled refugees } \\
\text { - Orientation to life in Canada - banking systems, } \\
\text { Canadian culture, shopping, transportation, etc. } \\
\text { - Temporary accommodation for resettled refugees; } \\
\text { refugee-specific shelters in large metropolitan areas } \\
\text { - Support in finding permanent accommodation }\end{array}$ & $\begin{array}{l}\text { - Resettlement Assistance } \\
\text { Program } \\
\text { - Immigrant Settlement and } \\
\text { Adaptation Program } \\
\text { - The Association for New } \\
\text { Canadians (St. John's, } \\
\text { Newfoundland) } \\
\text { - Romero House (Toronto) }\end{array}$ \\
\hline $\begin{array}{l}\text { 2. Employment } \\
\text { and Language }\end{array}$ & $\begin{array}{l}\text { - Job search techniques; resume-writing and interview skills, } \\
\text { job placement and bridge-to-work programs } \\
\text { - English language instruction; English language } \\
\text { conversation classes, job-related language training }\end{array}$ & $\begin{array}{l}\text { - Language Instruction for } \\
\text { Newcomers to Canada (LINC) } \\
\text { - Enhanced Language Training } \\
\text { (ELT) } \\
\text { - COSTI (Toronto) }\end{array}$ \\
\hline $\begin{array}{l}\text { 3. Social Capital; } \\
\text { Health and } \\
\text { Counselling; and } \\
\text { Family Support }\end{array}$ & $\begin{array}{l}\text { - Introduction to "Canadian" families } \\
\text { - Twinning and mentorship programs } \\
\text { - Settlement workers in schools } \\
\text { - Parenting classes } \\
\text { - Family counselling } \\
\text { - Women's groups } \\
\text { - Basic and emergency health cost coverage } \\
\text { - Specialized counselling and services for victims of trauma } \\
\text { and torture in some municipalities }\end{array}$ & $\begin{array}{l}\text { - HOST } \\
\text { - S.U.C.C.E.S.S (BC) } \\
\text { - Canadian Centre for Victims } \\
\text { of Torture (Toronto) } \\
\text { - Interim Federal Health } \\
\text { program }\end{array}$ \\
\hline
\end{tabular}

* See Annex for the full list.

cluded from most of federally and provincially funded integration services in all three categories. A few exceptions existed in some provinces and in large metropolitan areas, where locally funded organizations for refugees would extend their services to claimants.

In terms of service gaps, studies suggested that finding affordable permanent housing may be one of the greatest challenges facing refugees in the early stage of settlement. Regarding language and employment, some refugees may benefit from language training, employment services, and employment-related training targeted at newcomers with low levels of formal education. Refugees may also benefit from services on mental health and family counselling. However, a comprehensive study on the usage and effectiveness of the existing services is warranted before new programs are developed. ${ }^{42}$

\section{Conclusions: Summary, Research Gaps, and Service Gaps}

This article sought to summarize what is known about Canada's refugee integration patterns and service needs in order to identify research and service gaps. In terms of economic integration, although refugees' employment rates and earnings improve with time, they continue to perform less well than skilled-worker immigrants (but not family class). Among refugee categories, LCRs and PSRs outperform GARs at the first year after landing, but by the fifth year after landing, all categories show similar economic outcomes. In terms of socio-cultural integration, refugees are more likely than any other immigrant category to intend to apply for, to have applied for, or to have received Canadian citizenship. Refugees also appreciate the peaceful nature of Canada more than other immigrants.

Our literature review revealed that national-scale empirical studies on refugee integration in Canada are extremely scarce. Existing national-scale databases, such as IMDB and LSIC, could be more fully utilized, at least to replicate the existing studies of immigrant integration. For example, in addition to the descriptive analysis of refugees' economic and socio-cultural integration patterns, multiple regression analysis could be conducted to test whether and to what extent the factors influencing immigrants' integration apply to refugees. In other words, are refugees reporting less employment earnings than other immigrant categories because of their lower human capital, traumatic migration experience, or different social networks? More- 
over, since IMDB and LSIC are longitudinal databases, regression analysis would be even more meaningful given that integration is a process that occurs over a period of time and longitudinal analysis allows control for non-observable individual effects. Finally, as LCRs and the resettled PSRs and GARs exhibit distinctive characteristics, such as age, source country, and educational attainment, these groups should be studied separately whenever possible.

In terms of integration services, a number of federal, provincial/territorial, and local services and programs assist refugees by providing initial orientation, employment and/or social support. Many services cater to both immigrant and refugee populations while a smaller number specialize in refugees. PSRs, GARs, protected persons, and LCRs have similarly wide access to various integration services. However, because LCRs and protected persons will often have resided in Canada for some time, they are less likely to access some of the services. Refugee claimants, being temporary residents, have the least access to services, which tend to target permanent residents.

Our review identified a number of integration service gaps for refugees. First, refugees, especially GARs and PSRs with little formal education and minimal official language skills, may benefit from tailored employment and language programs. Using a similar concept to the federally funded Enhanced Language Training, which mostly addresses the employment needs of highly educated newcomers, a program targeting refugees (and immigrants) at the other, lower end of the educational spectrum may be worth exploring. Second, several small-scale studies suggest that refugees' heightened need for mental health and family counselling may need to be addressed. Finally, although not directly addressed in our review, we found two sub-national studies reporting on the spatial mismatch between service providers that are concentrated in traditional settlement (downtown) and multi-ethnic areas on the one hand and refugees (especially GARs) who settle outside these areas (suburbs, non-urban) or in ethnic communities located far from multi-ethnic service centres on the other. ${ }^{43}$

A final area worthy of further exploration regards the availability of integration services to refugee claimants. The debate for and against upfront integration services is polarized. Those arguing for services to be available to all claimants as soon as they submit their application maintain that these early services are a good investment for harmonious Canada since more than half of claimants do end up becoming permanent residents. They also argue that early integration services are congruent with Canada's international obligations and humanitarian values. On the other hand, those arguing against such services hold that providing integration services to the claimants who will in the end face removal may be costly and hard to justify. Moreover, they fear that such services would jeopardize the integrity of the in-Canada refugee protection system by creating a pull factor for an influx of unfounded claims. Empirical evidence to substantiate this debate is surprisingly sparse, if not nonexistent, in Canada. The few studies we located were mainly based on Europe and showed mixed findings on the impact of asylum policy (including access to benefits) on the number of refugee claimants. ${ }^{44}$ An empirical study examining the benefits and costs attached to providing integration services to claimants would be required to advance the current debate.

\section{Annex: List of Integration Services Available to Refugees in Canada}

The section 4 of this paper was partly based on an extensive search of federal, provincial and municipal websites, which snowballed into non-governmental service provider websites. The federal government has over 400 contribution agreements with various service providing organizations across the country. Among them, a sample of 51 service providing organizations was examined in greater details; they are listed below. In selecting the sample, an effort was made to look at a number of service providing organizations from each province; to identify services in major municipal centres and smaller refugee destinations; to balance services in urban vs. non-urban settings; to include services that were ethnicspecific as well as oriented towards the generic newcomers group; and to look at large integration service providers as well as smaller and more specialized organizations.

\section{Federal Funding Source/Program}

- Resettlement Assistance Program: RAP provides GARs with income support for one year, initial reception and temporary housing, and initial orientation to Canadian life.

- Interim Federal Health Program: IFH provides emergency health insurance ${ }^{\star *}$

- Language Instruction for Newcomers to Canada (LINC): Language classes

- Immigrant Settlement and Adaptation Program: Reception, orientation, interpretation and translation, employment, and counselling (excluding social and psycho-social counselling) services; Includes Enhanced Language Training, Canadian Orientation Abroad and Settlement Workers in Schools $(\text { SWIS })^{* *}$ programs

- HOST: Matches newcomers with volunteers 


\section{Provincial Funding Source/Program}

\section{British Columbia}

- Information and Support Services: Needs assessments, orientation, support and referral ${ }^{\star *}$

- Community Bridging Services: Matches newcomers with volunteers ${ }^{* *}$ (school-aged refugee claimants only)

- English Language Services for Adults: English language classes $^{\star *}$ (claimants outside of Lower Mainland and Greater Victoria only)

- Information Support and English Language Services for Adults: Provides English language training with support for cultural adjustment, orientation, referral for multibarriered immigrant and refugee newcomers ${ }^{* *}$

Alberta

- English as a Second Language: Language classes in Calgary and Edmonton*

- Bridging to Work programs: assists newcomers in obtaining work experience and upgrade skills

- Immigrant Settlement Program: (co-funded by CIC) orientation, interpretation/translation, referral, language assessments, employment readiness, and enhanced language training ${ }^{\star}$

Saskatchewan

- Community Partnerships and Settlement: language training, literacy training, employment services, orientation $^{*}$

\section{Manitoba}

- English as an Additional Language: English language classes**

- ENTRY program: Orientation ${ }^{\star *}$

\section{Ontario}

- Newcomer Settlement Program: Client needs assessments, referrals, orientation, employment services, and community development ${ }^{* *}$

Quebec

- Programme d'accompagnement des nouveaux arrivants: Referral and orientation, employment-related services, translation, assistance in finding housing** (housing search only)

- Programme d'appui aux relations civique et culturelles: Promote cultural understanding, encourage diversity and eliminate racism

- Programme d'aide financière pour l'intégration linguistique des immigrants : Language

New Brunswick

Nova Scotia

- Settlement Program Funding: A variety of settlement services including employment services

\section{Newfoundland and Labrador}

Prince Edward Island

- Employment Assistance Services: Job search skills and resume writing ${ }^{\star \star}$ (claimants with work permits only)

- Immigrant Student Liaison Program: Assists students in adapting to new environment and facilitates participation of parents in school system ${ }^{\star}$

\section{Local Service Providing Organizations}

\section{British Columbia}

- Abbotsford Community Services: Employment services, diversity education, language, legal advocacy and information, translation and interpretation, children/youth and senior specific programming, family support ${ }^{* *}$

- Immigrant Services Society of BC: Language, employment services, bridging for women, orientation and referral, counselling, family and youth programs, community development and capacity building $^{\star}$ (Language classes exclude claimants)

- Inland Refugee Society: Information and referral, housing support, financial and in-kind assistance to claimants, information on making refugee claims, language and life skills classes ${ }^{\star *}$

- MOSAIC: Employment services including case management, English for the workplace, computer orientation, language classes, family and youth programs, parenting, interpretation, information and support services, orientation, referral, legal advice ${ }^{\star *}$ (except for language classes)

- Pacific Immigrant Resources Society: Language classes, parenting and leadership classes for women*

- Surrey Delta Immigrant Services Society: Family services including counselling, support for victims of abuse, children with mental health issues, employment services, youth specific programming, parenting, interpretation and translation ${ }^{\star}$ (language classes exclude claimants)

- Vancouver Association for the Survivors of Torture: Specialized medical and settlement services to survivors of torture and their families, research and development of methods, and public education*

- S.U.C.C.E.S.S.: Specialized services for seniors, women, children and youth, reception, housing support, health services, employment services, counselling, school support, family support, legal clinics (excluding immigration law), recreation, information, newcomer- volunteer matching, language, public education, computer literacy, and translation* (language classes exclude claimants) 


\section{Alberta}

- Calgary Catholic Immigration Society: Orientation, referrals, translation, interpretation, housing referrals, recreational activities, non-therapeutic counselling, family resource centre and subsidized child care, seniors services, HOST, support program for survivors of torture, legal workshop series, employment services, language classes ${ }^{*}$

- Edmonton Mennonite Centre for Newcomers: Community development and capacity building, community-based counselling and counselling for survivors of torture and trauma, youth programs, cultural brokering in schools, language, employment services, programs for professionals, housing units*

- International Centre: Employment services, mentorship for foreign trained professionals, tutoring, translation and interpretation, nutrition education, cultural awareness education $^{* *}$ (translation and interpretation services are free for permanent residents only)

- Manitoba Interfaith Immigration Council Welcome Place: Referral, orientation, legal rights, housing support, interpretation, support in making a claim, and $\operatorname{advocacy}^{* *}$

- Needs Centre for War Affected Families (Winnipeg): Supports refugee and immigrant children, youth, adults affected by war, counselling, language and computer training, and family activities*

\section{Saskatchewan}

- Moosejaw Multicultural Council: Interpreters, translators, community outreach, space for group gatherings, language classes and HOST* (language classes and HOST exclude claimants)

- Regina Open Door Society: Orientation, referral, language classes and HOST, recreation, social activities, advocacy, youth programs, seniors groups, liaison, computer literacy, children's activities, interpretation and translation, employment services, family counselling and support, parenting*

- Saskatoon Open Door Society: Employment services, language classes, family support, parenting, and counselling* (language classes exclude claimants)

\section{Manitoba}

- Age and Opportunity (Winnipeg): Activities, and English classes for seniors*

- Jewish Child and Family Service: Orientation and needs assessment, referral, connect to schools, and employment services*

- Community Legal Education Association (Winnipeg): Courses on legal issues and free legal information on the phone

- Employment Projects of Winnipeg: Employment services $^{\star}$

- Employment Solutions for Immigrant Youth (Win-
- Fort Garry Community Network Immigrant and Refugee Outreach Program (Winnipeg): Home visits, referrals, organize community meetings*

- Immigrant Women's Counselling Services: Counselling for immigrant women with violence in

Ontario

- Arab Community Centre of Toronto: Information and referral, housing, legal assistance, translation, interpretation, counselling, parenting, orientation, employment services, legal services, cultural activities, and volunteer placements ${ }^{\star *}$

- Canadian Centre for Victims of Torture (Toronto): Medical, mental health and social care, legal help, crisis intervention, art therapy, community support, support groups, and counselling*

- COSTI (Toronto): Language, youth and children services, employment services, counselling and mental health services, referral, orientation, temporary accommodation, women and seniors services, and computer literacy ${ }^{\star *}$

- Ethiopian Association in the GTA: Reception, orientation, counselling, referral, employment services, case management, mental health counselling, HIV/AIDS prevention, and language ${ }^{\star}$ (language classes exclude claimants)

- Newcomer Women's Services of Toronto: Employment services, language, life skills development, volunteer opportunities, counselling, referral, and legal assistance $^{\star}$ (language classes exclude claimants)

- Toronto Chinese Community Services Association: Counselling, orientation, employment services, computer services, language, women and seniors support groups, parenting programs, children and youth programming*

- Romero House (Toronto): Subsidized housing for refugee claimants, conversation classes, women's group, community events, employment services, housing support, paralegal services, translation, advocacy $^{* *}$

- Vietnamese Association Toronto: Settlement and adaptation services, employment services, domestic violence prevention, gambling counselling, family and youth at-risk counselling, language, advocacy, translation and interpretation* (settlement and adaptation services exclude claimants)

- London Cross Cultural Learning Centre: Orientation, referral, counselling, employment services, language, HOST, and translation ${ }^{\star}$

- OCISO (Ottawa): Housing support, legal aid services, settlement counselling, orientation, job search workshops, women's programming, language, counselling and psychotherapy, multicultural liaison officer in schools, summer camp, and community development ${ }^{\star}$ 
Quebec

- Access Travail : Employment services ${ }^{*}$

- Accueil et integration Bas-Saint-Laurent : Referral, orientation and public education ${ }^{\star}$

- Carrefour d'aide aux nouveaux arrivants : Orientation, information, interpretation, housing support, language, legal information, parenting*

- CASA C.A.F.I. (Montreal): Legal information, orientation, referral, translation, employment services, housing support, parenting, school liaison, programs for older immigrants, and language classes*

- R.I.R.E. (Montreal): Computer literacy, language classes, community education, programs for professionals, youth placements* (language classes and youth placements exclude claimants)

- L'Hirondelle (Quebec): Information, orientation, translation, housing search, interpretation, liaison, family summer camps, language classes, employment counselling, referrals, newcomer-volunteer twinning, and mentoring*

- La Maisonnee (Quebec): Language, employment services, orientation, support in making claims, legal information, interpretation, housing support, homework help, mentoring, inter-cultural twin$\operatorname{ning}^{* *}$

- Services et formation aux immigrants en Monteregie: Orientation, referral, employment services, language classes $^{*}$

New Brunswick

- English Language Program University of New Brunswick: Language classes*

- Multicultural Association of Fredericton: Language classes, employment services, summer camps, computer skills, public education ${ }^{\star *}$ (except for language classes)

- Multicultural Association of the Greater Moncton Area: ISAP funded settlement services, language classes and HOST program

- St. John YM-YWCA: General recreational programs open to the public ${ }^{* *}$

Nova Scotia

- Halifax Immigrant Learning Centre: Language and literacy programs, English in the Workplace, computer literacy

- Metropolitan Immigrant Settlement Association (Halifax): Assessment, referral, follow-up, orientation, out-reach in homes and schools, intervention support, language assessment, employment services, and cultural and family awareness ${ }^{\star}$

- YMCA Centre for Immigrant Programs (Halifax): Youth outreach and school support ${ }^{* *}$
- Centre for Diverse Visible Cultures (Halifax): Language, literacy, computer literacy, information, legal advice, bereavement support, family counselling and support, translation, and recreation ${ }^{* *}$

Newfoundland and Labrador

- The Association for New Canadians (St. John's Newfoundland): Housing search, orientation, referral support in making a claim, interpretation, translation, public education, women's group, social and recreational programming, tutoring, language, employment services ${ }^{\star \star}$ (except for language classes)

\section{Prince Edward Island}

- PEI Association for Newcomers to Canada: Programme D’Établissement des francophones including housing search support, referral, interpretation, matching with volunteers, community awareness, employment services; Internationally educated health professionals program; language testing*

- * It is unclear whether some or all services are/are not provided to claimants unless otherwise specified.

- $* \star$ Services are provided to claimants as well as to resettled refugees, LCRs and protected persons unless otherwise specified.

\section{Notes}

1. Citizenship and Immigration Canada, Facts and Figures 2005: Immigration Overview - Permanent and Temporary Residents (Ottawa: Minister of Public Works and Government Services, 2006), 3.

2. Following is a list of studies on refugee integration at the subnational level in chronological order: Joseph H. Michalski and Youssef Habib, "A Study of Iraqi Refugees: Final Report" (Toronto: Centre for Applied Social Research, University of Toronto, 1997); Usha George and Ka Tat Tsang, "The Settlement and Adaptation of Formerly-Yugoslavian Newcomers" (Toronto: Faculty of Social Work, University of Toronto, 1998); Morton Beiser, Angela Shik, and Monika Curyk, "New Canadian Children and Youth Study Literature Review" (for Health Canada, March 31, 1999); Neita Kay Israelite, Arlene Herman, Faduma Ahmed Alim, Hawa Abdullahi Mohamed, and Yasmin Khan, "Settlement Experiences of Somali Refugee Women in Toronto" (presentation, Seventh International Congress of Somali Studies, York University, Toronto, July 1999); Samuel Noh, Morton Beiser, Violet Kaspar, Feng Hou, and Joanna Rummens, "Perceived Racial Discrimination, Depression, and Coping: A Study of Southeast Asian Refugees in Canada," Journal of Health and Social Behavior 40, no. 3 (September 1999): 193-207; Usha George and M. S. Mwarigha, "Consultation on Settlement Programming for African Newcomers," Final Report for Citizenship and Immigration Canada, Ontario Adminstration of Settlement and Integration Services (Toronto: Centre for Applied Social Research, Faculty 
of Social Work, University of Toronto, 1999); Monica Boyd, "Gender, Refugee Status and Permanent Settlement," Gender Issues 17, no. 3 (1999): 5-25; Morton Beiser, Strangers at the Gate: The "Boat People's" First Ten Years in Canada (Toronto: University of Toronto Press, 1999); Baha Abu-Laban, Tracey Derwing, Harvey Krahn, Marlene Mulder, and Lori Wilkinson, "The Resettlement of Refugees in Alberta 1992-1997" (Edmonton: PCERII and the Population Research Laboratory, University of Alberta, 1999); Faranak Miraftab, "Sheltering Refugees: The Housing Experience of Refugees in Metropolitan Vancouver," Canadian Journal of Urban Research 9, no. 1 (June 2000): 42-63; Morton Beiser and Feng Hou, "Gender Differences in Language Acquisition and Employment Consequences among Southeast Asian Refugees in Canada," Canadian Public Policy / Analyse de Politiques 26, no. 3 (September 2000): 311-330; Harvey Krahn, Tracey Derwing, Marlene Mulder, and Lori Wilkinson, "Educated and Underemployed: Refugee Experiences in the Alberta Labour Market," Journal of International Migration and Integration 1, no. 1 (2000): 59-84; Kenise Murphy Kilbride, Paul Anisef, Etta Baichman-Anisef, and Randa Khattar, "Between Two Worlds: The Experiences and Concerns of Immigrant Youth in Ontario" (Toronto: CERIS, 2000); Paul Anisef and Kenise Murphy Kilbride, "The Needs of Newcomer Youth and Emerging 'Best Practices' to Meet Those Needs," Final Report to the Settlement Directorate, Ontario Region, Citizenship and Immigration Canada (Toronto: CERIS, 2000); Gillian Creese and Robyn Dowling, "Gendering Immigration: The Experience of Women in Sydney and Vancouver," Working Paper No. 01-04 (Vancouver: RIIM, January 2001); Jeff Chenoweth and Laura Burdick, "The Path to Integration: Meeting the Special Needs of Refugee Elders in Resettlement." Refuge 20, no. 1 (November 2001):20-29; E. Pittaway and Linda Bartolomei, "Refugees, Race and Gender," Refuge 19 (2001): 21-32; Morton Beiser and Feng Hou, "Language Acquisition, Unemployment and Depressive Disorder among Southeast Asian Refugees: A 10-Year Study," Social Science and Medicine 53 (2001): 1321-1334; Rose Damaris and Brian Ray, "Le logement des réfugiés à Montréal trois ans après leur arrivée : le cas des demandeurs d'asile ayant obtenu la résidence permanente," Journal of International Migration and Integration/ Revue de l'intégration et de la migration internationale 2, no. 4 (2001): 455-92; Dan Hiebert, "Canadian Immigration and the Selection-Settlement Services Trade-off: Exploring Immigrant Economic Participation in British Columbia," Working Paper No. 02-05 (Vancouver: RIIM, February 2002); Lori Wilkinson, "Factors Influencing the Academic Success of Refugee Youth in Canada," Journal of Youth Studies 5, no. 2 (June 2002): 173-193; Morton Beiser, "Ethnic Identity, Resettlement Stress and Depressive Affect Among Southeast Asians in Canada," Working Paper No. 17 (Toronto: CERIS, October 2002); Xin Ma, "The First Ten Years in Canada: A Multi-Level Assessment of Behavioural and Emotional Problems of Immigrant Children," $\mathrm{Ca}$ nadian Public Policy 28, no. 3 (2002); Dan Hiebert, "Are Immigrants Welcome? Introducing the Vancouver Community Studies Survey," Working Paper No. 03-06 (Vancouver: RIIM, March 2003); Joanna Anneke Rummens and Rajko Seat, "Assessing the Impact of Kosovo Conflict on the Mental Health and Well Being of Newcomer Serbian Children and Youth in the Greater Toronto Area," Working Paper No. 25 (Toronto: CERIS, May 2003); Tracey M. Derwing and Marlene Mulder, "The Kosovar Sponsoring Experience in Northern Alberta," Working Paper No. WP05-03 (Edmonton: PCERII, September 2003); Morton Beiser, L. Simich, and N. Pandalangat, "Community in Distress: Mental Health Needs and Help-seeking in the Tamil Community in Toronto," International Migration 41, no. 5 (December 2003): 233-245; Jean Renaud, Victor Piché, and Jean-François Godin, "One’s Bad and the Other One's Worse: Differences in Economic Integration Between Asylum Seekers and Refugees Selected Abroad," Canadian Ethnic Studies/Études ethniques au Canada 35, no. 2 (2003): 86-133; Kathy Sherrell, Jennifer Hyndman, and Fisnik Preniqi, "Sharing the Wealth, Spreading the Burden? The Settlement of Kosovar Refugees in Small B.C. Cities," Working Paper No. 04-06 (Vancouver: RIIM, February 2004); "The Study of Sudanese Settlement in Ontario: Final Report" (Citizenship and Immigration Canada, Settlement Directorate, Ontario, May 28, 2004); Kathy Sherrell and Jennifer Hyndman, "Global Minds, Local Bodies: Kosovar Transnational Connections Beyond British Columbia.” Working Paper No. 04-10 (Vancouver: RIIM, May 2004); Haile Fenta, Ilene Hyman, and Samuel Noh, "Determinants of Depression among Ethiopian Immigrants and Refugees in Toronto," Journal of Nervous and Mental Health Disease 192, no. 5 (May 2004): 363-372; Robert A. Murdie, "Pathways to Housing: The Experiences of Sponsored Refugees and Refugee Claimants in Accessing Permanent Housing in Toronto" (Toronto: CERIS, May 2005); Morton Beiser, Linda Ogilvie, Joanna Anneke Rummens, Robert Armstrong, and Jacqueline Oxman-Martinez, "The New Canadian Children and Youth Study: Research to Fill a Gap in Canada's Children's Agenda," Canadian Issues/Thèmes canadiens, Special Issue on Immigration and Intersections of Diversity (May 2005); Dan Hiebert, "Research on Immigration and Integration in the Metropolis," Commentary Series Working Paper No. 05-04 (Vancouver: RIIM, July 2005); Craig Watson "Integration of Government Assisted Refugees in British Columbia" (Vancouver: Faculty of Arts and Sciences, Simon Fraser University, Spring 2006); James McLean, Chris Friesen, and Jennifer Hyndman, "The First 365 Days: Acehnese Refugees in Vancouver, British Columbia," Working Paper No. 06-07 (Vancouver: RIIM, June 2006); Feng Hou and Morton Beiser, "Learning the Language of a New Country: A Tenyear Study of English Acquisition by South-East Asian Refugees in Canada," International Migration 44, no. 1 (2006): 135-165.

3. The term "integration" is used loosely in this paper to refer to a relatively harmonious pluralist model of diversity.

4. UK Home Office, Integration: Mapping the Field (Croyden: Home Office, 2003), 113.

5. Augie Fleras and Jean Leonard Elliot, Multiculturalism in Canada: The Challenge of Diversity (Scarborough: Nelson Canada, 1992); Augie Fleras and Jean Leonard Elliot, Unequal Relations: An Introduction to Race, Ethnic and Aboriginal Dynamics in Canada (Scarborough: Prentice Hall Canada, 1996); Peter S. Li, "The Multiculturalism Debate," in Race and Ethnic 
Relations in Canada, $2^{\text {nd }}$ ed., ed. P. S. Lee (Oxford: Oxford University Press, 1999); Gertrud Neuwirth, “Toward a Theory of Immigrant Integration," in Immigrant Canada: Demographic, Economic and Social Challenges, ed. S. S. Halli and L. Driedger (Toronto: University of Toronto Press, 1999).

6. Citizenship and Immigration Canada, Facts and Figures 2005: Immigration Overview - Permanent and Temporary Residents (Ottawa: Minister of Public Works and Government Services, 2006).

7. Characteristics of refugees and immigrants granted permanent residence in 2005 (PAs and dependents) are shown in the table on the right.

8. The table below provides historic figures based on Facts and Figures 2005, Citizenship and Immigration Canada. "FC" stands for Family Class and "SWPA" for Skilled Worker Principal Applicants.

9. The distribution discussed here is of aggregated totals (combining principal applicants and dependents) within each category.

\begin{tabular}{||l|l|l|l|l|l|l|l||}
\hline \multirow{2}{*}{ Gender } & LCRs & GARs & PSRs & $\begin{array}{l}\text { Family } \\
\text { Class }\end{array}$ & $\begin{array}{l}\text { Skilled } \\
\text { Workers }\end{array}$ & All \\
\cline { 2 - 9 } & Women & $46 \%$ & $50 \%$ & $52 \%$ & $47 \%$ & $53 \%$ & $49 \%$ \\
\hline \multirow{3}{*}{ Age } & 0 to 14 & $15 \%$ & $37 \%$ & $26 \%$ & $26 \%$ & $12 \%$ & $22 \%$ \\
\cline { 2 - 9 } & 15 to 44 & $69 \%$ & $54 \%$ & $65 \%$ & $67 \%$ & $69 \%$ & $66 \%$ \\
\hline \begin{tabular}{l|l}
45 and \\
over
\end{tabular} & $16 \%$ & $9 \%$ & $10 \%$ & $8 \%$ & $19 \%$ & $13 \%$ \\
\hline \multirow{3}{*}{$\begin{array}{l}\text { Areas } \\
\text { of } \\
\text { Birth }\end{array}$} & $\begin{array}{l}\text { Middle- } \\
\text { East/ } \\
\text { Africa }\end{array}$ & $27 \%$ & $42 \%$ & $64 \%$ & $20 \%$ & $12 \%$ & $19 \%$ \\
\cline { 2 - 8 } & Asia/Pacific & $30 \%$ & $29 \%$ & $29 \%$ & $54 \%$ & $58 \%$ & $53 \%$ \\
\cline { 2 - 8 } & $\begin{array}{l}\text { Latin } \\
\text { America }\end{array}$ & $30 \%$ & $21 \%$ & $5 \%$ & $8 \%$ & $18 \%$ & $13 \%$ \\
\cline { 2 - 8 } & $\begin{array}{l}\text { Europe \& } \\
\text { Central } \\
\text { Asia }\end{array}$ & $13 \%$ & $9 \%$ & $3 \%$ & $18 \%$ & $12 \%$ & $16 \%$ \\
\hline Total & Total & 19,935 & 7,416 & 2,976 & 63,352 & 130,242 & 262,236 \\
\hline
\end{tabular}

(Source: Facts and Figures 2005, Citizenship and Immigration Canada)

\begin{tabular}{|c|c|c|c|c|c|c|c|c|c|c|c|c|c|}
\hline \multicolumn{14}{|c|}{ Per cent women by category by landing year, 1990-2005 } \\
\hline & 1990 & 1991 & 1992 & 1993 & 1994 & 1995 & 1996 & 1997 & 1998 & 1999 & 2000 & 2001 & 2002 \\
\hline LCRs & 33 & 36 & 38 & 43 & 40 & 41 & 41 & 41 & 42 & 42 & 42 & 42 & 43 \\
\hline GARs & 40 & 43 & 44 & 44 & 47 & 46 & 47 & 43 & 46 & 47 & 48 & 48 & 47 \\
\hline PSRs & 40 & 38 & 38 & 41 & 45 & 46 & 48 & 47 & 48 & 47 & 46 & 48 & 50 \\
\hline $\mathrm{FC}$ & 55 & 56 & 57 & 58 & 58 & 58 & 59 & 60 & 61 & 61 & 62 & 61 & 61 \\
\hline SWPA & 33 & 40 & 42 & 42 & 32 & 32 & 30 & 29 & 28 & 25 & 24 & 25 & 25 \\
\hline \multicolumn{14}{|c|}{ Per cent aged 14 and under by category by landing year, 1990-2005 } \\
\hline & 1990 & 1991 & 1992 & 1993 & 1994 & 1995 & 1996 & 1997 & 1998 & 1999 & 2000 & 2001 & 2002 \\
\hline LCRs & 18 & 20 & 19 & 21 & 16 & 16 & 18 & 17 & 19 & 19 & 18 & 17 & 16 \\
\hline GARs & 27 & 31 & 32 & 30 & 31 & 30 & 31 & 31 & 32 & 32 & 34 & 34 & 33 \\
\hline PSRs & 21 & 18 & 17 & 19 & 23 & 27 & 28 & 29 & 28 & 32 & 27 & 30 & 24 \\
\hline $\mathrm{FC}$ & 13 & 12 & 14 & 16 & 14 & 14 & 14 & 14 & 15 & 14 & 12 & 12 & 12 \\
\hline SWPA & 0 & 0 & 0 & 0 & 0 & 0 & 0 & 0 & 0 & 0 & 0 & 0 & 0 \\
\hline \multicolumn{14}{|c|}{ Per cent from Middle East and Africa by category by landing year, 1990-2005 } \\
\hline & 1990 & 1991 & 1992 & 1993 & 1994 & 1995 & 1996 & 1997 & 1998 & 1999 & 2000 & 2001 & 2002 \\
\hline LCRs & 48 & 58 & 47 & 41 & 30 & 28 & 37 & 40 & 45 & 44 & 37 & 33 & 31 \\
\hline GARs & 24 & 32 & 35 & 37 & 23 & 20 & 22 & 28 & 23 & 27 & 32 & 41 & 49 \\
\hline PSRs & 16 & 21 & 26 & 34 & 35 & 35 & 38 & 27 & 29 & 30 & 41 & 40 & 44 \\
\hline $\mathrm{FC}$ & 9 & 10 & 9 & 10 & 9 & 10 & 10 & 10 & 10 & 11 & 12 & 12 & 10 \\
\hline SWPA & 23 & 18 & 16 & 14 & 15 & 16 & 15 & 16 & 18 & 17 & 16 & 20 & 23 \\
\hline \multicolumn{14}{|c|}{$\begin{array}{l}\text { Per cent with thirteen or more years of education, trade certificates or university degree or above } \\
\text { among fifteen years and older by category by landing year, 1990-2005 }\end{array}$} \\
\hline LCRs & 41 & 37 & 37 & 35 & 42 & 35 & 38 & 39 & 36 & 34 & 35 & 37 & 37 \\
\hline GARs & 28 & 20 & 18 & 22 & 33 & 40 & 36 & 33 & 33 & 32 & 22 & 20 & 16 \\
\hline PSRs & 43 & 42 & 40 & 31 & 26 & 31 & 29 & 33 & 30 & 29 & 25 & 24 & 20 \\
\hline FC & 31 & 31 & 30 & 28 & 27 & 28 & 32 & 34 & 37 & 40 & 41 & 43 & 43 \\
\hline SWPA & 69 & 68 & 64 & 69 & 81 & 87 & 90 & 92 & 94 & 96 & 97 & 97 & 98 \\
\hline
\end{tabular}


10. This total includes all immigrants and refugees who were granted permanent residence in 2005, of which the categories presented in this table are only a part. For example, this table does not include business and investment classes.

11. This section is based on two sources. First, a systematic and exhaustive search of literature in five databases (Econolit, CSA illumine, ABI/INFORM Global, Web of science and JStor) for publications within the last ten years containing the following keywords was conducted: "refugees and Canada" with integration, assimilation, settlement, adjustment, adaptation, social, cohesion, or enclaves. Second, two nationally representative survey data, LSIC and IMDB, were analyzed. Unfortunately, neither could clearly report on the effect of Canada's most recent shift in selection policies with respect to the effect of the "ability to establish" regulatory criterion (Immigration and Refugee Protection Act 2002) due to its relatively recent introduction.

12. LSIC "refugee" figure also includes a few "refugees abroad."

13. Albeit being the best source of data for economic outcomes of refugees, IMDB only contain information about refugees who filed an income tax only (approximately 40 to 50 per cent of past arrivals). Conclusions should be made with caution.

14. There are strong reasons to believe that GARs who arrived in 1994 and 1995 were highly educated refugees from the Bosnia and Herzegovina conflict of 1992-1995 in Europe: see Steven L. Burg and Paul S. Shoup, The War in Bosnia-Herzegovina: Ethnic Conflict and International Intervention (Amonck: M. E. Sharpe, 1999); "Bosnia and Herzegovina - Canadian Aid," online: DFAIT-MAECI Homepage, <http://www.dfait-maeci. gc.ca/canada-europa/> (accessed 11 May 2007).

CIC data as shown below also clearly demonstrates that the proportion of GARs originating from Bosnia-Herzegovina and its neighbour country, Croatia, increased substantially in 1993 and 1994.

GARs from Bosnia-Herzegovina and Croatia, by landing year

\begin{tabular}{|c|c|c|c|c|c|c|c|c|c|}
\hline Cohort & 1990 & 1991 & 1992 & 1993 & 1994 & 1995 & 199 & 1997 & 1998 \\
\hline $\begin{array}{l}\% \text { of GARs } \\
\text { from } \\
\text { Bosnia-Herzeg } \\
\text { ovina }\end{array}$ & $0.0 \%$ & $0.0 \%$ & $60.0 \%$ & $\begin{array}{c}0 \\
0 \\
\%\end{array}$ & $\begin{array}{l}49.8 \\
\%\end{array}$ & $\begin{array}{l}63.6 \\
\%\end{array}$ & $\begin{array}{l}56.7 \\
\%\end{array}$ & $\begin{array}{l}41.9 \\
\%\end{array}$ & $\begin{array}{l}41.7 \\
\%\end{array}$ \\
\hline $\begin{array}{l}\% \% \text { of GARs } \\
\text { from Bosnia- } \\
\text { Herzegovina } \\
\text { with } \\
\text { bachelors } \\
\text { degree }\end{array}$ & N/A & $\mathrm{N} / \mathrm{A}$ & N/A & $19 \%$ & $24 \%$ & $16 \%$ & $11 \%$ & $7 \%$ & $5 \%$ \\
\hline
\end{tabular}

Source: Facts and Figures 2005, Citizenship and Immigration Canada

Data also show that these GARs cohorts were highly educated.
Proportion of Refugees with a Bachelor's Degree; Their Respective Aver age Earnings in \$1000, 1995-2003 Tax Years

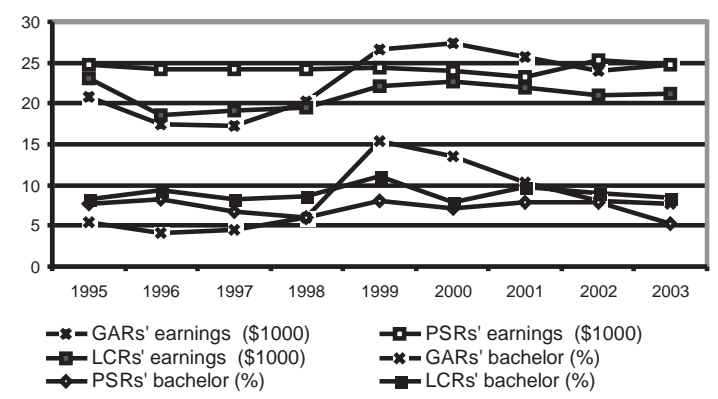

Sources: Facts and Figures 2005, Citizenship and Immigration Canada, and Longitudinal Immigration Database (IMDB), Compendium Tables 2003, Statistics Canada, online: IMDB-BDIM

Homepage, www24.statcan.ca (accessed 11 May 2007).

15. Don DeVoretz, Sergyi Pivnenko, and Morton Beiser, "The Economic Experience of Refugees in Canada," RIIM Working Paper No.04-04 (Vancouver: Centre of Excellence for Research on Immigration and Integration in the Metropolis, May 2004), 17.

16. Grant Schellenberg and Hélène Maheux, "Immigrants' Perspectives on Their First Four Years in Canada: Highlights from Three Waves of the Longitudinal Survey of Immigrants to Canada," Canadian Social Trends (Ottawa: Statistics Canada, April 2007), 34, online: <http://www.statcan.ca/english/freepub/ 11-008-XIE/2007000/pdf/11-008-XIE20070009627.pdf>

17. The citizenship figures were presented by another variable on expectations about life in Canada. Since it was impossible to disaggregate the table, we decided to show the original ranges.

18. Navjot K. Lamba, "Social Capital and Refugee Resettlement: The Social Networks of Refugees in Canada," Journal of International Migration and Integration 3 (2003): 335-360. The study examined GARs and PSRs who were destined to Alberta between 1992 and 1997, and excludes LCRs. At the time of the interviews, approximately 85 per cent were still in Alberta while 15 per cent had migrated to Ontario or British Columbia.

19. Navjot K. Lamba, “The Employment Experiences of Canadian Refugees: Measuring the Impact of Human and Social Capital on Quality of Employment," Candian Review of Sociology and Anthropology 1(2003): 59.

20. Citizenship and Immigration Canada, Terms and Conditions, Settlement Contribution Programs, April 1, 2005 - March 31, 2010.

21. Murdie, "Pathways to Housing," 8.

22. City of Toronto, Toronto Report Card on Homelessness 2001, (2001).

23. Immigration et Communautés Culturelles Québec, Programmes, <http://www.micc.gouv.qc.ca/fr/programmes.html> (accessed 1 May 2007).

24. Bushra Junaid, "First Contact: The Arrival Needs of Refugee Claimants," (December 12, 2002).

(C) Soojin Yu, Estelle Ouellet and Angelyn Warmington, 2007. This open-access work is licensed under a Creative Commons AttributionNonCommercial 4.0 International License, which permits use, reproduction and distribution in any medium for non-commercial purposes, provided the original author(s) are credited and the original publication in Refuge: Canada's Journal on Refugees is cited. 
25. Citizenship and Immigration Canada, Summative Evaluation of the Private Sponsorship of Refugees Program (January 2007), 32 .

26. Evaluation of Performance Measurements Strategic Planning Division, Priorities, Planning and Research Branch, CIC. Evaluation of the Resettlement Assistance Program. (Citizenship and Immigration Canada, 2004), 20.

27. Miraftab.

28. Murdie, "Pathways to Housing," 12; Immigrant Services Society of British Columbia, New Beginnings: Insights of Government-Assisted Refugees in British Columbia into Their Settlement Outcomes (Vancouver: December 2006), 39.

29. Ibid., 30.

30. Ibid., 38 .

31. Ministry of Citizenship and Immigration Ontario, Newcomer Settlement Program, <http://www.citizenship.gov.on.ca/english/citdiv/immigrat/newcomer.htm \#8> (accessed 1 May 2007); Nova Scotia Office of Immigration, Settlement Program Funding, <http://www.novascotiaimmigration.com/enpage1041.aspx> (accessed 1 May 2007).

32. Citizenship and Immigration Canada, Facts and Figures 2005.

33. Citizenship and Immigration Canada, Longitudinal Survey of Immigrants to Canada (LISC) 2001 (2001).

34. David L.E. Watt and Deidre M. Lake, Benchmarking Adult Rates of Second Language Learning. Alberta Learning - Language Training Programs.(Calgary: University of Calgary and Canadian Language Research and Consulting, 2004).

35. Citizenship and Immigration Canada, Facts and Figures 2005. 36. Renaud, Piché, and Godin.

37. Morton Beiser, "The Health of Immigrants and Refugees in Canada," Canadian Journal of Public Health 96 (2005).

38. Small sample studies have shown that conflict and trauma result in high levels of post-traumatic stress disorder (PTSD). Ministry of Health, Indonesia, Psychological Needs Assessment of Communities Affected by the Conflict in the Districts of Pidie, Bireuen, and Aceh Utara (2006); Joanna Anneke Rummens, Assessing the Impact of the Kosovo Conflict on the Mental Health and Wellbeing of Newcomer Serbian Children and Youth in the Greater Toronto Area-Summary Research Report (2000-2002).

39. UNHCR, Taking Account Gender, <http://www.unhcr.org/protect/PROTECTION/3d98627f4.pdf> (accessed 1 May 07).

40. "Inner-city Refugee Women: Lessons for Public Policy," in State of the Inner-City: 2006 (Manitoba: Canadian Centre for Policy Alternatives, 2006), http://www.policyalternatives.ca/ Reports/2006/11/ReportsStudies1504/index.cfm?pa=BB736 455 .

41. In this case, a newcomer family is one with settlement needs, normally experienced within the first two years in Canada.
42. All of CIC's existing settlement programs have been recently evaluated. These evaluations identify some of the strengths and weaknesses of existing settlement programs. An in-depth analysis of these documents and programs would be useful to determine whether identified service gaps could be addressed within the framework of existing programs. Evaluation reports available at $<$ http://www.cic.gc.ca $>$ are: "Evaluation of the Immigrant Settlement and Adaptation Program" (2005), "Evaluation of the HOST Program" (2004), "Evaluation of the Resettlement Assistance Program" (2004), and the "Evaluation of the Language Instruction for Newcomers to Canada Program" (2004).

43. Marie Truelove, "Services for Immigrant Women: An Evaluation of Locations," Canadian Geographer 44, no.2 (Summer 2000); Kareem D. Sadiq, "The Two-Tier Settlement System: A Review of Current Newcomer Settlement Services in Canada," (November 2004).

44. US Citizenship and Immigration Services, This Month in Immigration History: January 1995, < http://149.101.23.2/graphics/ aboutus/history/anchor9985> (accessed 7 May 2007); Timothy J. Hatten, "Seeking Asylum in Europe," Economic Policy (April 2003), 36; Vaughan Robinson and Jeremy Segrott, Understanding the Decision-Making of Asylum Seekers (Home Office Research, Development and Statistics Directorate, 2002), 1, $<$ http://www.homeoffice.gov.uk/rds/pdfs2/r172.pdf >; Silva Ferretti, David Griffiths, Martyn Pearl, and Roger Zetter, An Assessment of the Impact of Asylum Policies in Europe 1990-2000 (UK Home Office, 2003), 1, <http://www.homeoffice.gov.uk/ rds/pdfs2/r168.pdf >; Eiko R. Thielemann, "Does Policy Matter? On Governments' Attempts to Control Unwanted Migration," School of Public Policy Working Paper Series: ISSN 1479-9472 (London: November 2003), 28.

Soojin $Y u$ is a Senior Advisor for the Refugees Branch of Citizenship and Immigration Canada. Estelle Ouellet, formerly with Citizenship and Immigration Canada, is a Trade Policy Officer with the Department of Foreign Affairs and International Trade. Angelyn Warmington is a Junior Policy Advisor for the Refugees Branch of Citizenship and Immigration Canada. The authors would like to thank colleagues and friends for their helpful comments throughout the multiple versions of this article. The views expressed in this paper are those of the authors' and do not necessarily reflect the official views of Citizenship and Immigration Canada. 